\title{
Work-integrated Learning Competencies: A Case Study in a Food Engineering Practice School Program
}

\section{Ekarut Ruayruay}

Ph.D. candidate, College of Multidisciplinary Sciences, King Mongkut's University of Technology Thonburi, Thailand, eakarut.rua@ kmutt.ac.th

Krissanapong Kirtikara

School of Energy, Envi. and Mater., KMUTT, Thailand, krissanapong.kir@kmutt.ac.th

\section{Montira Nopharatana}

Asst. Prof., Faculty of Engineering, KMUTT, Thailand, montira.nop@kmutt.ac.th

\section{Komkrit Chomsuwan}

Asst. Prof., Faculty of Industrial Education and Technology, KMUTT, Thailand, komkrit.cho@kmutt.ac.th

\section{Sasitorn Suwannathep}

Asst. Prof., School of Liberal Arts, KMUTT, Thailand, sasithon.suw@kmutt.ac.th

There is increasing pressure on higher education to include work-integrated learning (WiL) in its programs in order to prepare graduates for the workplace. However, there is a lack of detailed competencies required for this type of learning. The purpose of this study was to identify competencies needed for workintegrated learning (WiL). The case study took place in a food engineering practice school program in a Thai university. It involved multiple quantitative and qualitative data-collection techniques over a period of one year including interviews, observation, focus groups and surveys. Participants included alumni, instructors, administrators, graduate students, site directors, managers, a factory CEO, support staff and mentors. Results revealed six core competencies as follows: ethics and integrity; continuous learning skills, problem-solving and research skills, leadership and teamwork skills, communication skills with English language, and knowledge of food engineering. Analysis using Pearson Product Moment Coefficient of Correlation indicated that continuous learning skills, leadership and teamwork skills and problem-solving and research skills emerged as the most important competencies.

Keywords: competencies, work-integrated learning, food engineering, leadership

Citation: Ruayruay, E., Kirtikara, K., Nopharatana, M., Chomsuwan, K., \& Suwannathep, S. (2020). Work-integrated Learning Competencies: A Case Study in a Food Engineering Practice School Program. International Journal of Instruction, 13(2), 707-720. https://doi.org/10.29333/iji.2020.13248a 


\section{INTRODUCTION}

Higher education (HE) has an important role to play in helping students to develop competencies and skills that can prepare them not only to contribute to society and achieve personnel development but to be equipped for the workplace (Council on Higher Education, 2001). As a result, there is increasing pressure on HE to include work-integrated learning (WiL) in its programs in order to prepare graduates for the workplace (Spowart, 2006). WiL may be referred to as internship, professional practice, co-op education or experiential learning and involves integrating work-related activities and experiences into students' academic programs (Leong \& Kavanagh, 2013). WiL involves industry and HE collaborating to improve learning by supporting application of knowledge by students, and by integrating theory and practice to improve future employability (Ermis, 2015). WiL may include a variety of activities including observation and reflection on practice but the emphasis is on practical learning (Assan, 2014).

Researchers have identified many benefits of WiL. These include an opportunity to gain "business acumen and real world experience" (Leong \& Kavanagh, 2013, p. 1). Wil also provides an opportunity to develop both social and professional skills (Gillett-Swan \& Grant-Smith, 2018), computer and technical skills (Rambe, 2018), skills related to teamwork, organization, ethics, and critical analysis (Brahimi, Dweiri, Syouf \& Khan, 2013 , p. 448), and skills related to "teamwork, professional judgment, communication, and problem-solving" (Rowe \& Zegwaard, 2017, p. 4). WiL also offers opportunities for students to gain experience working with others such as management and customers (Buted, Felicen \& Manzano, 2014). In some contexts of WiL international placements, students gain opportunities to improve foreign-language communication skills and to gain insights and understanding of cultural differences (Reinhard \& Pogrzeba, 2016). Jackson (2015) observed that WiL improved students' employability, work-readiness and general understanding of the world of work and helped them integrate theory with practice.

Preparing graduates for the workplace means developing competencies such as problemsolving, self-regulation and emotional awareness (Tillema, Kessels \& Meijers, 2000). Competencies involve "a combination of skills, abilities, and knowledge needed to perform a specific task" (Cheng, Wang, Yang, Kinshuk, \& Peng, 2011, p. 2). They have also been defined as "identified behaviours, knowledge, skills, and abilities that directly and positively impact the success of employees and organizations" (Buted, Felicen \& Manzano, 2014, p.57). Kavanagh and Drennan (2008) observed that WiL students need a combination of technical skills, business awareness and real-world understanding. Other competencies include an ability to engage in critical, analytical, and creative thinking as well as problem solving and interpersonal and communication skills (Leong \& Kavanagh, 2013). Makhathini (2016) found that while students in a chemical engineering WiL were able to demonstrate cognitive skills, they lacked behavioral skills. The authors concluded that, for students to be effective and have the technical competence in their WiL placements, they need development of their soft skills. Sattler and Peters' (2012) Canadian study revealed the largest challenge facing WiL employers was students' lack of soft skills. 
One area in which WiL can play an important role in terms of meeting industry and learning needs is in food engineering. Food engineering (FE) can be defined as "the branch of engineering that deals with the technology of large-scale food production" (Niranjan, 2016, p.14). It has also been defined as "the identification and creation of physical principles associated with foods and ingredients, and the application of the principles to the handling, storage, processing, packaging and distribution of consumer food products" (Heldman \& Lund, 2011, p.5). This industry is an important one because it directly contributes to the economic health of countries and the well-being of its citizens (Niranjan, 2016). Food engineering itself relates to complex issues of health and obesity, the environment and security (Niranjan, 2016). In spite of its importance in society and globally, as Niranjan (2016) explained, food-engineering programs do not always receive dedicated attention in engineering institutes. Instead, such programs often exist as an "abridged version" of some larger engineering programs such as chemical engineering. Niranjan (2016) argued that there is an imperative need for food engineering to establish its own identity particularly in light of forces and dynamics related to business, the market, manufacturing and environmental considerations.

Niranjan (2016) observed, regarding the discipline of food engineering as a whole, that it requires a "broader science base" with more adequate definition and delineation of competencies required of graduates (p. 1). However, these competencies have yet to be identified. The need for competencies is complex because students involved in WiL must have competencies for the domain of learning as well as for the workplace (Buted, Felicen \& Manzano, 2014, p. 57). Specifically in relation to WiL and food engineering, Weston, Crilly, Mossop and Foster (2017) in the United Kingdom, noted that "the food industry does not have a cohesive competency framework to support employers, students and degree providers" (p. 101). Weston (2019) highlighted the potential value of such a framework for students in terms of career planning as well as for their own personal development. Weston (2019) also argued that knowing these competencies would help those delivering education programs to refine them to better meet the needs of the industry. More broadly, Wakeham (2016) argued that increasing growth in technology and innovation put pressure on higher education to produce more STEM (Science, Technology, Engineering) graduates with the required skills and competencies needed for industry.

The study reported on in this paper was motivated by the need to develop competency frameworks in food engineering. The purpose of this study was to identify the competencies need for WiL in a context of food engineering. Results of this study will be of interest to those designing and delivering food engineering programs that have a WiL component as well as for those designing and delivering WiL programs in other areas. The specific objectives were as follows:

1. Design a competency framework for work-integrated learning in food engineering practice;

2. Identify stakeholders' perspectives on the importance of the different competencies;

3. Identify the relationship between these competencies. 


\begin{abstract}
METHOD
This research involved a case study to investigate "a contemporary phenomenon within its real-life context" (Yin, 2003, p. 13). The case study was conducted in a Food Engineering Practice School Program in Bangkok, Thailand that operates both at the university and at the worksite. Data collection was carried out at the university and the worksite. Collection relied on both qualitative and quantitative techniques with participants representing different perspectives on the phenomenon under study. Data collection was guided by the Lesson Learned Method (Malele, Mpofu \& Muchie, 2017), by the Stufflebeam Context Input Process Product Evaluation Model (Hasan, Yasin \& Yunus, 2015) as well as by After-Action Review (Jennings, Killeen, \& Miles, 2018).
\end{abstract}

Ethics' procedures followed those consistent with requirements of the university in which the principal investigator (PI) was a Ph.D. candidate. Participants were informed that their participation was voluntary, that results would be anonymous, confidential and aggregated. They were also informed that they could withdraw at any time and that their participation or non-participation would not affect their role. The interviews and focus groups were conducted in the university and were recorded electronically. Observation took place during university courses as well as during workshops and other activities. All interviews were recorded with participants' consent.

\title{
Context of the Research
}

In the two-year FEPS' program, students spend three semesters on campus in eight courses/workshops and examine case studies and real-world PBL about factory food production. They spend one semester onsite in a food manufacturing factory. They have six lectures/courses in food engineering (FE) and complete two problem-based learning (PBL) courses with extensive teamwork. The PBL is designed to allow students to transfer knowledge and skills from university to the worksite. Materials are in English, lectures are $80 \%$ in English and students practice English skills by giving presentations and writing reports. Industry experts visit classes to offer knowledge and insights not available in literature. Workshops and activities help students learn soft skills including self-understanding as well as about academic integrity (misconduct, falsification, plagiarism). Instructors in the FE department work as advisors with students. A site director is responsible for managing learning in the factory. Project management officers coordinate interactions between university and industry. The program is funded through tuition fees and budget support per head from government, and additional budget from external agencies, both public and private sectors. Students gain knowledge from teachers and from experiences.

\section{Data Collection}

Objective 1 was accomplished through multiple data-collection techniques that included on-site observation, interviews and focus group sessions. Participants included instructors, students, administrators, support staff and alumni of the Food Engineering Practice School (FEPS). The researchers interviewed five FEPS' instructors for two hours each and observed one cohort with one instructor and 15 students, one to two 
hours per week for two semesters at the university. The researchers interviewed two FEPS' administrators and one support staff member for two hours each. The researchers conducted separate three-hour focus groups with the cohort of 15 FEPS' students in two groups as well as a two-hour focus group with three FEPS' alumni.

Data collection also took place at the work site, i.e., in the food production factory. This phase of data collection involved observation of five FEPS' students and one site director for two days per week for five months. It also involved indivdual two-hour interviews with one CEO, one manager and two engineering mentors and two program sponsors. Observation took place at all parts of the factory where students were participating in learning. The observation and interviews were guided by semi-structured questions designed to provide a holistic overview of the context.

Objective 2 involved administration of surveys to allow stakeholders the opportunity to provide their perspectives on the importance of the competencies developed in objective 1. Participants included eight graduate students, seven university administrators, and seven engineering mentors. The survey required approximately 15 to 20 minutes for completion. In objective 3 , to determine relationships between the competencies, the researchers administered an online survey to 205 alumni from eight different WiL programs in the university. Table 1 outlines the number of years they had graduated from the program. The survey required approximately one hour for completion. The survey was created using the 120 indicators of FEP competency identified in objective 1. The survey was distributed using Google Forms with survey links sent using emails as well as Line and Facebook applications.

Table 1

Participants (Objective 3)

\begin{tabular}{lll}
\hline Years graduated & $\mathrm{N}$ & $\mathbf{( \% )}$ \\
\hline$<1$ & 7 & 3 \\
$1-5$ & 85 & 41 \\
$6-10$ & 30 & 15 \\
$11-15$ & 23 & 11 \\
$16-20$ & 16 & 8 \\
$>20$ & 36 & 18 \\
Missing & 8 & 4 \\
\hline Total & 205 & 100 \\
\hline
\end{tabular}

\section{Analysis}

Data collection resulted in a large corpus of qualitative data. The first step involved aggregating and summarizing data from different sources through inductive analysis (Glaser \& Strauss, 1967) and the creation of categories (Silverman, 2006). It also involved data reduction (Miles \& Huberman, 1994) to eliminate data that were not relevant to the questions. Following analysis, two program administrators completed member checking to enhance validation (Lincoln \& Guba, 1985). Analysis led to the creation of the competency framework. Creation of the content of the framework was guided by the Index of Item-Objective Congruence (IOC). The IOC test was conducted by seven experts. These included one competency developer, one curriculum developer, 
one education evaluator and five FE experts. The results revealed that the value of IOC was 0.969 which is higher than the standard. Inter-rater reliability was tested by two site directors in charge of students' research in an industrial department along with three students. The accuracy value was $0.683,0.73$ and 0.726 respectively which is acceptable criteria in statistics.

The data analysis for objective 2 relied on calculation of description statistics in terms of percentages related to participants' perceptions of the importance of six competencies of WiL in food engineering. Researchers used the Analytic Hierarchy Process (Kim, Park $\&$ Choi, 2017) to prioritize the competencies. Data analysis for objective 3 relied on mean and standard deviation to rank the importance of FEPS competencies according to participants' perspectives. Pearson Product Moment Coefficient of Correlation (Kurtz \& Mayo, 1978) was used to determine if there was a statistically significant relationship between the competencies.

\section{FINDINGS}

Analysis of data from objective 1 data collection resulted in the creation of a competency framework with six competencies (table 2) with five levels (table 3) and 120 indicators. Figure 1 gives an example of one indicator for each level.

Table 2

The Six Competencies

\begin{tabular}{lll}
\hline No & Competencies in FEPS & \multicolumn{1}{c}{ Definition } \\
\hline 1 & $\begin{array}{l}\text { Continuous learning skills } \\
\text { (CLS). }\end{array}$ & $\begin{array}{l}\text { Explore information \& learn new things by thinking, } \\
\text { observing, questioning, \& obtaining answers by oneself. }\end{array}$ \\
\hline 2 & $\begin{array}{l}\text { Leadership and Teamwork } \\
\text { Skills (LTS) }\end{array}$ & $\begin{array}{l}\text { Successfully achieve all assigned tasks by being a good } \\
\text { team member able to collaborate \& exchange knowledge } \\
\text { with the team \& related parties. }\end{array}$ \\
\hline 3 & $\begin{array}{l}\text { Problem-Solving and } \\
\text { Research Skills (PRS) }\end{array}$ & $\begin{array}{l}\text { Analyze main problems of FPP at the industrial level by } \\
\text { using academic principles of research. }\end{array}$ \\
\hline 4 & $\begin{array}{l}\text { Communication Skills with } \\
\text { English Language (CSE) }\end{array}$ & $\begin{array}{l}\text { Use English to communicate with others by giving } \\
\text { presentations, exchanging \& expressing opinions, etc. }\end{array}$ \\
\hline 5 & $\begin{array}{l}\text { Knowledge of Food } \\
\text { Engineering (KFE) }\end{array}$ & $\begin{array}{l}\text { Integrate concepts \& knowledge of FS \& FPE \& apply to } \\
\text { problem-solving \& improving the industrial process. }\end{array}$ \\
\hline 6 & Ethics and Integrity (EI) & $\begin{array}{l}\text { Act righteously as encoded in the code of ethics; sustain } \\
\text { integrity at work, \& don't ignore problems. }\end{array}$ \\
\hline
\end{tabular}

Table 3

Competency Levels

\begin{tabular}{lll}
\hline Level & Level Name & Level definitions \\
\hline 1 & Basic (B) & $\begin{array}{l}\text { An initial stage of practice working under a framework or a } \\
\text { specific method. }\end{array}$ \\
\hline 2 & Task (T): & Action completed by oneself or with help from team. \\
\hline 3 & Developing (D): & Ability to lead members in designing \& creating new things. \\
\hline 4 & Advanced (A): & $\begin{array}{l}\text { Analyze \& use new ideas to reinforce organizational efficiency \& } \\
\text { competency in teaching others to demonstrate specific behaviors. }\end{array}$ \\
\hline 5 & Expert (E): & Able to advise others about organizational work processes. \\
\hline
\end{tabular}




\begin{tabular}{|c|c|c|c|c|c|}
\hline & B & 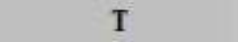 & D & A & E \\
\hline$\frac{3}{3}$ & $\begin{array}{l}\text { Identify knowledge } \\
\text { for assigned tasks. }\end{array}$ & $\begin{array}{l}\text { Find occupational } \\
\text { information from } \\
\text { documents, } \\
\text { textbooks \& } \\
\text { academic joumals. }\end{array}$ & $\begin{array}{l}\text { Help others gather } \\
\text { new information } \\
\text { by working } \\
\text { together to } \\
\text { complete tasks. }\end{array}$ & $\begin{array}{l}\text { Analyze } \\
\text { knowledge \& } \\
\text { select new ideas } \\
\text { to improve work } \\
\text { efficiency. }\end{array}$ & $\begin{array}{l}\text { Synthesize information } \\
\text { from various resources } \\
\text { to improve } \\
\text { performance in } \\
\text { organization. }\end{array}$ \\
\hline$\stackrel{5}{2}$ & $\begin{array}{l}\text { Acknowledge } \\
\text { goals \& werk } \\
\text { progress of the } \\
\text { team }\end{array}$ & $\begin{array}{l}\text { Participate in } \\
\text { defining work plan } \\
\text { of the team. }\end{array}$ & $\begin{array}{l}\text { Contribute to } \\
\text { setting up } \\
\text { directions \& goals } \\
\text { of the team. }\end{array}$ & $\begin{array}{l}\text { Show confidence } \\
\text { in thoughts, words } \\
\& \text { actions. }\end{array}$ & $\begin{array}{l}\text { Define alternatives for } \\
\text { complicated situations } \\
\text { or complex problems. }\end{array}$ \\
\hline$\frac{\mathscr{a}}{a}$ & $\begin{array}{l}\text { Identify the root } \\
\text { cause of problems } \\
\text { arising from one's } \\
\text { duties. }\end{array}$ & $\begin{array}{l}\text { Discover problems } \\
\text { within FPP under } \\
\text { supervision of } \\
\text { experts. }\end{array}$ & $\begin{array}{l}\text { Identify the root } \\
\text { cause of problems } \\
\text { in FPP. }\end{array}$ & $\begin{array}{l}\text { Identify problems } \\
\text { that impact the } \\
\text { organization. }\end{array}$ & $\begin{array}{l}\text { Identify problems that } \\
\text { highly impact the } \\
\text { organization in the } \\
\text { production process. }\end{array}$ \\
\hline 战 & $\begin{array}{l}\text { Recognize \& } \\
\text { understand English } \\
\text { vocabulary in } \\
\text { general \& relevant } \\
\text { to FE. }\end{array}$ & $\begin{array}{l}\text { Take notes during } \\
\text { work on site in } \\
\text { English. }\end{array}$ & $\begin{array}{l}\text { Write technical } \\
\text { reports in English } \\
\text { to communicate } \\
\text { with team. }\end{array}$ & $\begin{array}{l}\text { Write research } \\
\text { report in English } \\
\text { to communicate } \\
\text { with others. }\end{array}$ & $\begin{array}{l}\text { Prepare articles or } \\
\text { documents in English } \\
\text { to communicate with } \\
\text { others. }\end{array}$ \\
\hline 2 & $\begin{array}{l}\text { Explain key } \\
\text { concepts of FE. }\end{array}$ & $\begin{array}{l}\text { Explain relationship } \\
\text { between science \& } \\
\text { engineering in FPP. }\end{array}$ & $\begin{array}{l}\text { Apply knowledge } \\
\text { of FE to industrial } \\
\text { work practices. }\end{array}$ & $\begin{array}{l}\text { Adapt knowledge } \\
\text { to the working } \\
\text { procedures of the } \\
\text { FPP. }\end{array}$ & $\begin{array}{l}\text { Representative of } \\
\text { organization to transfer } \\
\text { knowledge \& } \\
\text { experience to others. }\end{array}$ \\
\hline 古 & $\begin{array}{l}\text { Conduct tasks } \\
\text { without accusing } \\
\text { others. }\end{array}$ & $\begin{array}{l}\text { Know \& understand } \\
\text { work ethic of the } \\
\text { organization. }\end{array}$ & $\begin{array}{l}\text { Consult code of } \\
\text { conduct. }\end{array}$ & $\begin{array}{l}\text { Suggest the code } \\
\text { of ethics \& } \\
\text { guidelines to the } \\
\text { team members. }\end{array}$ & $\begin{array}{l}\text { Be a good example for } \\
\text { employees in the } \\
\text { organization to follow } \\
\text { in professional ethics. }\end{array}$ \\
\hline
\end{tabular}

Figure 1

Example of Competency Indicators (from a total of 120)

\section{Objective 2}

Table 4 presents the results of analysis of data collected for objective 2 to identify the relative importance of competencies from the perspective of stakeholders. For all three groups of participants, the lowest ranked competency was Communication Skills with English Language (CSE). For administrators, the highest ranked in importance was Ethics and Integrity (EI). For engineering mentors, the highest ranked in importance was Leadership and Teamwork skills (LTS). For graduate students, the highest ranked in importance was Problem-Solving and Research Skills (PRS). 
Table 4

Ranking of Importance of FEPS Competencies

\begin{tabular}{|c|c|c|c|}
\hline \multirow[t]{2}{*}{ Competencies } & \multicolumn{3}{|c|}{ FEPS competencies Ranking } \\
\hline & $\begin{array}{l}\text { University administrator } \\
(\mathrm{N}=7)(\%)\end{array}$ & $\begin{array}{l}\text { Engineering mentors } \\
(\mathrm{N}=7)(\%)\end{array}$ & $\begin{array}{l}\text { Graduate students } \\
(\mathrm{N}=8)(\%)\end{array}$ \\
\hline CLS & 14 & 17 & 18 \\
\hline LTS & 11 & 21 & 17 \\
\hline PRS & 13 & 18 & 21 \\
\hline CSE & 4 & 11 & 12 \\
\hline KFE & 17 & 20 & 13 \\
\hline EI & 41 & 13 & 19 \\
\hline
\end{tabular}

Note: CLS = Continuous Learning Skills/ KFE = Knowledge of Food Engineering/

For the 205 alumni, the most important competency was that of Ethics and Integrity. This result is consistent with the perception of the seven administrators. The second most important was Continuous Learning Skills which was not ranked in importance by either administrators, mentors or graduates. The third most important was Leadership and Teamwork Skills. This competency was ranked highest as well by the seven engineering mentors. The fourth competency was that of Problem-Solving and Research Skills which was also ranked highest by the eight graduate students. The fifth competency was Knowledge of Food Engineering and the sixth or lowest ranked was that of Communication Skills with English. This competency was also the lowest ranked as with the first group of participants.

\section{Objective 3}

Table 5 and figure 2 show that the correlations of six competencies were significant at the 0.01 level $(\alpha<0.01)$. The value of correlations showed that CLS- LTS, PRS-CLS and LTS-PRS have a higher correlation $(\mathrm{r}>0.7)$. The results show that the correlation values are $0.784,0.744$ and 0.763 respectively. The relationship between EI-LTS and EI-PRS showed a correlation value of 0.653 and 0.620 respectively. This means that although Ethics and Integrity was ranked the highest by administrators as well as the 205 alumni, it was not correlated with the other competencies. Therefore, Continuous Learning Skills, Leadership and Teamwork Skills and Problem-Solving and Research Skills emerged as the most important competencies.

Table 5

Descriptive Statistics and Correlation of Six Competencies ( $\mathrm{N}=205)$

\begin{tabular}{|c|c|c|c|c|c|c|c|c|}
\hline \multirow[t]{2}{*}{ Competency } & \multicolumn{2}{|c|}{$\begin{array}{l}\text { Descriptive } \\
\text { Statistics }\end{array}$} & \multicolumn{6}{|c|}{ Pearson Product Moment Coefficient of Correlation } \\
\hline & Mean & SD & CLS & LTS & PRS & CES & KFE & EI \\
\hline CLS & 4.231 & .409 & - & & & & & \\
\hline LTS & 4.267 & .454 & $.784 * *$ & - & & & & \\
\hline PRS & 4.112 & .482 & $.744 * *$ & $.763 * *$ & - & & & \\
\hline CSE & 3.546 & .812 & $.380 * *$ & $.368 * *$ & $.425^{* *}$ & - & & \\
\hline KFE & 4.034 & .560 & $.569^{* *}$ & $.597 * *$ & $.696 * *$ & $.529 * *$ & - & \\
\hline EI & 4.349 & .508 & $.536^{* *}$ & $.653 * *$ & $.620 * *$ & $.267 * *$ & $.586 * *$ & - \\
\hline
\end{tabular}




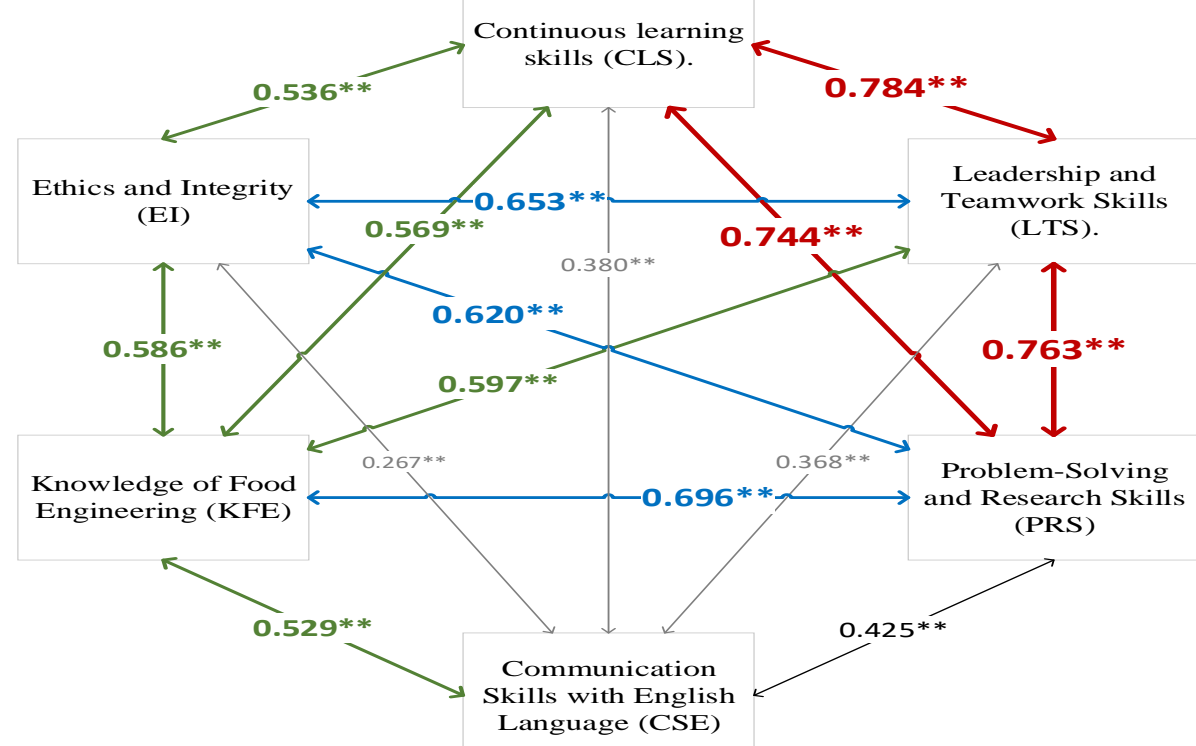

Figure 2

Correlation of Six Competencies of WiL in Food Engineering

\section{DISCUSSION}

The purpose of this study was to identify competencies needed for work-integrated learning (WiL). The case study took place in Thailand within a food engineering practice school program and involved multiple data-collection techniques over a period of one year including interviews, observation, focus groups and surveys. Participants included alumni, instructors, administrators, graduate students, site directors, managers, a factory CEO, support staff and mentors. Results revealed six competencies required by the food industry as follows: ethics and integrity; continuous learning skills, problem-solving and research skills, leadership and teamwork skills, communication skills with English language, and knowledge of food engineering. Analysis using Pearson Product Moment Coefficient of Correlation indicated that continuous learning skills, leadership and teamwork skills and problem-solving and research skills emerged as the most important competencies.

Results regarding the importance of leadership are confirmed by the findings of a WiL program by Freudenberg, Brimble, and Cameron (2011) who found that employers and students ranked teamwork, initiative and communication skills as most important. In this study, however, communication skills were not ranked as the most important competency. Fleming, Martin, and Zinn (2009) argued that relationship building, teamwork and cooperation can actually help develop communication skills. Also, Basadur (2004) found that creative leadership depended on defining and solving problems, a process that required common language for effective communication. 
Similarly, Druskat and Wheeler's (2003) research revealed that effective leadership depended on effective listening skills. Jiang, Lee, and Golab (2015) identified both leadership and continuous learning as important in cooperative learning. In this study, lifelong/continuous learning was not ranked as most important. In spite of the importance of leadership and team-work skills, in their study, Edgar and Connaughton (2014) found that these skills were rarely taught.

Continuous learning skills also ranked highly. Not surprisingly, Ibrahim, Jaafar, and Pertanika (2017) argued that lifelong, continuous learning was important for graduates' employability, career motivation and upward mobility. In Cushen's (2005) study, 90\% of respondents noted that their learning mostly took place outside the formal educational settings and that their university learning focused on theory. Cushen (2005) also found that for employers, academic activities needed to be accompanied by practical experiences. Regarding problem-solving and research skills, these are related to teamwork skills since problem-solving can help teams learn from mistakes (Tjosvold, Yu \& Hui, 2004). WiL provides an opportunity to convert the theory learned in the classroom into problem-solving (Jonassen, Strobel, \& Lee, 2006). In relation to communication and English skills, Fleming, Martin and Zinn (2009) determined that work placements helped students develop various soft skills including communication skills. In Australia, Barrie et al. (2009) in relation to a WiL framework in accounting, found that students needed skills related to communications, teamwork and problem-solving.

\section{CONCLUSIONS}

Results of this study suggested that competencies necessary for WiL are leadership and teamwork skills, continuous learning as well as problem-solving and research skills were the most important WiL competencies. The competency of ethics and integrity was ranked the highest by administrators as well as by the 205 alumni but it was not correlated with the other competencies. Yet, ethics and integrity have been identified as highly important and even fundamental competencies in other contexts. Campbell and Zegwaard (2012) discussed this competencey in broader terms of critical moral agency. Campbell and Zegwaard claimed that values and ethics represent key elements of professionalism. They argued that these elements are developed not through indoctrination but through individual examination and critique. They further argued the following: "Students should graduate with the capacity to enact values-driven decisionmaking" (p. 21). This implies that learners in practice settings such as those in WiL enter not as tabula rasa or blank slates but have a capacity for development of critical moral agency. The agency develops through individual transitions in the workplace as a social context in which individuals make decisions and form practices (Campbell \& Zegwaard, 2012).

If, as this study indicated, leadership and teamwork skills are ranked as most important, then can these competencies facilitate relation of critical moral agency and/or the development of ethics, integrity and values? This is a question that might be investigated in future studies. Regardless of which competency is ranked highest, students require a context in which to develop skills related to leadership, communication, continuous 
learning etc.. Are these competencies best developed in the university or workplace setting? Campbell and Zegwaard (2012) outlined some approaches to development of certain competencies. These approaches include but are not limited to providing opportunities for dialogue (e.g., student-mentor) and self-reflection.

\section{LIMITATIONS}

The study was limited to one university and one program (food engineering) and in one country only. External validity should be measured by readers in terms of relevance of results to their own contexts. FEP programs in other contexts might make use of the framework as a starting point for development of their own frameworks, or use it directly to develop programs and curricula. This study relied on participants' perspectives which may not necessarily represent the actual phenomenon. For this reason, observation was used to triangulate data collection and correct, to some degree, for participants' biases. Reliance on self-report measures and personal perspectives raises the issue of how to determine if competencies are actually achieved. Future studies might investigate how the competencies identified in this study might be assessed.

\section{REFERENCES}

Assan, T. E. (2014). Work integrated learning (WIL): A phenomenographic study of student-teachers' experiences. Mediterranean Journal of Social Sciences, 5(7), 300-306. doi: $10.5901 / \mathrm{mjss} .2014 . v 5 \mathrm{n} 7 \mathrm{p} 300$.

Barrie, S. C., Hughes, C., \& Smith, C. (2009). The national graduate attributes project: Integration and assessment of graduate attributes in curriculum (Research Report). Strawberry Hills, Australia: Australian Learning and Teaching Council.

Basadur, M. (2004). Leading others to think innovatively together: Creative leadership. The Leadership Quarterly, 15(1), 103-121. doi:10.1016/j.leaqua.2003.12.007.

Brahimi, N., Dweiri, F., Al-Syouf, I., \& Khan, S. A. (2013). Cooperative education in an industrial engineering program. Procedia - Social and Behavioral Sciences, 102(1), 446-453. doi:10.1016/j.sbspro.2013.10.760.

Buted, D. R., Felicen, S. S., \& Manzano, A. I. (2014). A Correlation study between student performance in food and beverage services course and internship in F\&B department of hospitality business. International Journal of Academic Research in Business and Social Sciences, 4(6). doi:10.6007/ijarbss/v4-i6/924.

Campbell, M., \& Zegwaard, K. (2012). Values, ethics and empowering the self through cooperative education. Asia-Pacific Journal of Cooperative Education, 13, 205-216.

Cheng, B., Wang, M., Yang, S. J., Kinshuk, \& Peng, J. (2011). Acceptance of competency-based workplace e-learning systems: Effects of individual and peer learning $\begin{array}{llll}\text { support. Computers } \quad \& \quad \text { Education, } & \text { 1317-1333. }\end{array}$ doi:10.1016/j.compedu.2011.01.018. 
Council on Higher Education. (2001). A new academic policy for programmes and qualifications in higher education. Retrieved from https://www.che.ac.za/sites/default/files/publications/New_academic_Policy.pdf.

Cushen, J. (2005). Stakeholder perceptions of work-integrated learning: Analysis and recommendations (Unpublished doctoral dissertation). University of Otago.

Druskat, V. U., \& Wheeler, J. V. (2003). Managing from the boundary: the effective leadership of self-managing work teams. Academy of Management Journal, 46(4), 435457. doi:10.5465/30040637.

Edgar, S., \& Connaughton, J. (2014). Exploring the role and skill set of physiotherapy clinical educators in work-integrated learning. Asia-Pacific Journal of Cooperative Education, 15(1), 29-36.

Ermis, E. (2015). Effects of industry-integrated learning on employability skill outcomes - views of Food Engineering students. FooD-STA Virtual Conference "UniversityIndustry educational and training initiatives, University of Natural Resources and Life Sciences, Vienna (BOKU), Austria.

Fleming, J., Martin, A., Hughes, L. \& Zinn, C. (2009). Maximizing work integrated learning experiences through identifying graduate competencies for employability: A case study of sport studies in higher education. Asia-Pacific Journal of Cooperative Education, 10(3), 189-201.

Freudenberg, B., Brimble, M., \& Cameron, C. (2011). WIL and generic skill development: The development of business students' generic skills through workintegrated learning. Asia-Pacific Journal of Cooperative Education, 12(2), 79-93.

Gillett-Swan J., \& Grant-Smith D. (2018). A framework for managing the impacts of work-integrated learning on student quality of life. International Journal of WorkIntegrated Learning, 19(2), 129-140.

Glaser, B., \& Strauss, A. (1967). The discovery of grounded theory: Strategies for qualitative research. New York: Aldine.

Hasan, A., Yasin, S. N., \& Yunus, M. F. (2015). A conceptual framework for mechatronics curriculum using Stufflebeam CIPP Evaluation Model. Procedia - Social and Behavioral Sciences, 195, 844-849. doi:10.1016/j.sbspro.2015.06.324.

Heldman D. R., \& Lund D. B. (2011). The beginning, current, and future of food engineering: A perspective. Food engineering series. New York, NY: Springer.

Ibrahim, H. I., \& Jaafar, A. H. (2017). The outcomes of work-integrated learning programmes: The role of self-confidence as mediator between interpersonal and selfmanagement skills and motivation to learn. Journal of Social Sciences \& Humanities, 25(2), 931-948. 
Jackson, D. (2015). The contribution of work-integrated learning to undergraduate employability skill outcomes. Asia-Pacific Journal of Cooperative Education, 14(2), 99-115.

Jennings, B., Killeen, T. \& Miles, S. (2018). Applying the after action review (AAR) method to undergraduate medical curriculum development. AMEE International Conference, Congress Center Basel, Switzerland.

Jiang, Y., Lee, S., \& Golab L. (2015). Analyzing student and employer satisfaction with cooperative education through multiple data sources. Asia-Pacific Journal of Cooperative Education, 16(4), 225-240.

Jonassen, D., Strobel, J., \& Lee, C. B. (2006). Everyday problem solving in engineering: Lessons for engineering educators. Journal of Engineering Education, 95(2), 139-151. doi:10.1002/j.2168-9830.2006.tb00885.x.

Kavanagh, M. H., \& Drennan, L. (2008). What skills and attributes does an accounting graduate need? Evidence from student perceptions and employer expectations. Accounting \& Finance, 48(2), 279-300. doi:10.1111/j.1467-629x.2007.00245.x.

Kim, N., Park, J., \& Choi, J. (2017). Perceptual differences in core competencies between tourism industry practitioners and students using Analytic Hierarchy Process (AHP). Journal of Hospitality, Leisure, Sport \& Tourism Education, 20, 76-86. doi:10.1016/j.jhlste.2017.04.003.

Kurtz A.K., \& Mayo S.T. (1978). Pearson product moment coefficient of correlation. In Workbook for statistical methods in education and psychology. New York: Springer.

Leong, R., \& Kavanagh, M. (2013). A work-integrated learning (WIL) framework to develop graduate skills and attributes in an Australian university's accounting program. Asia-Pacific Journal of Cooperative Education, 14(1), 1-14.

Lincoln, Y. S., \& Guba, E. G. (1989). Ethics: The failure of positivist science. The Review of Higher Education, 12(3), 221-240. doi:10.1353/rhe.1989.0017.

Makhathini, T. P. (2016). Work integrated learning competencies: Industrial supervisors' perspectives. Perspectives in Education, 34(3). doi:10.18820/2519593x/pie.v34i3.5.

Malele, V., Mpofu, K., \& Muchie, M. (2017). Lesson learned from exposing computer systems engineering students to entrepreneurship and innovation activities. Conference on South African Society for Engineering Education, Cape Town, South Africa.

Miles, M. B., Huberman, A. M., Huberman, M. A., \& Huberman, P. M. (1994). Qualitative data analysis: An expanded sourcebook. Thousand Oaks, CA: SAGE.

Niranjan, K. (2016). A possible reconceptualization of food engineering discipline. Food and Bioproducts Processing, 99, 78-89. doi:10.1016/j.fbp.2016.04.003. 
Rambe, P. (2018). Using work integrated learning programmes as a strategy to broaden academic and workplace competencies. SA Journal of Human Resource Management, 16. doi:10.4102/sajhrm.v16i0.999.

Reinhard, K., \& Pogrzeba, A. (2016). Comparative cooperative education: Evaluating Thai models on work-integrated learning, using the German Duale Hochschule BadenWuerttemberg model as a benchmark. Asia-Pacific Journal of Cooperative Education, 17(3), 227-247.

Rowe A. D., \& Zegwaard K. E. (2017). Developing graduate employability skills and attributes: Curriculum enhancement through work-integrated learning. Asia-Pacific Journal of Cooperative Education, 18(2), 87-99.

Sattler, P., \& Peters, J. (2012). Work-integrated learning and postsecondary graduates: the perspective of Ontario employers. Toronto: Higher Education Quality Council of Ontario.

Silverman, D. (2006). Interpreting qualitative data: Methods for analyzing talk, text and interaction. Thousand Oaks, CA: SAGE.

Spowart, J. (2006). Hotel school students' views of their preparation for work-integrated learning: An exploratory study. Asia-Pacific Journal of Cooperative Education, 7(2), $10-15$.

Tillema, H. H., Kessels, J. W., \& Meijers, F. (2000). Competencies as building blocks for integrating assessment with instruction in vocational education: A case from the Netherlands. Assessment \& Evaluation in Higher Education, 25(3), 265-278. doi:10.1080/02602930050135130.

Tjosvold, D., Yu, Z., \& Hui, C. (2004). Team learning from mistakes: The contribution of cooperative goals and problem-solving. Journal of Management Studies, 41(7), 1223-1245. doi:10.1111/j.1467-6486.2004.00473.x.

Wakeham, W. (2016). Wakeham review of STEM degree provision and graduate employability (Research report). Department for Business, Innovation and Skills and Higher Education Funding Council for England.

Weston, E. (2019). Competencies for food graduate careers (Unpublished doctoral dissertation). University of Nottingham. UK.

Weston, E., Crilly, J., Mossop, L., \& Foster, T. (2017). Competencies for food graduate careers: Developing a language tool. Higher Education Pedagogies, 2(1), 101-115. doi:10.1080/23752696.2017.1366275.

Yin, R. K. (2003). Case study research: Design and methods. Thousand Oaks, CA: SAGE. 